\title{
Virulence of Botryosphaeria dothidea and Botryosphaeria obtusa on Apple and Management of Stem Cankers with Fungicides
}

\author{
Diane E. Brown-Rytlewski and Patricia S. McManus, Department of Plant Pathology, University of Wisconsin, \\ Madison 53706
}

\begin{abstract}
Brown-Rytlewski, D. E., and McManus, P. S. 2000. Virulence of Botryosphaeria dothidea and Botryosphaeria obtusa on apple and management of stem cankers with fungicides. Plant Dis. 84:1031-1037.

The virulence of isolates of Botryosphaeria dothidea and B. obtusa was compared on apple fruit, trunks of 2-year-old apple trees, and twigs of mature apple trees. In general, $B$. dothidea isolates were more virulent than $B$. obtusa isolates. There was no correlation between virulence on fruit and virulence on 2-year-old trees. Several compounds were tested as topical wound treatments to control stem cankers caused by B. dothidea and B. obtusa. Benomyl, kresoximmethyl, and trifloxystrobin, when applied at rates recommended for foliar application, consistently reduced the incidence and size of cankers compared with the water control. Clove oil, garlic extract, and neem oil did not reduce the incidence and size of cankers compared with the water control. Kresoxim-methyl was also effective when applied with an air-blast sprayer, despite incomplete spray coverage. Although fungicides reduced external canker symptoms, $B$. dothidea and $B$. obtusa were frequently isolated from xylem tissue, suggesting that fungicides might not provide long-term control of these pathogens.
\end{abstract}

Additional keywords: black rot, Bot rot, chemical control, Fusicoccum aesculi, Physalospora obtusa, Sphaeropsis malorum, white rot

Botryosphaeria dothidea (Moug.:Fr.) Ces. \& De Not. and Botryosphaeria obtusa (Schwein.) Shoemaker (syn. Physalospora obtusa (Schwein.) Cooke) cause the apple diseases white rot and black rot, respectively. Named for their symptoms on apple fruit, the diseases can cause severe crop loss, especially in warm, humid regions where apples are grown. Both pathogens also cause stem cankers that can kill scaffold limbs and entire trees. In cooler temperate climates, the role of Botryosphaeria spp. as canker pathogens may be more economically important than their role in producing fruit rots. Trees weakened by low-temperature injury and drought stress are especially susceptible to canker pathogens, including Botryosphaeria spp. $(6,18,19,29)$.

Variation in virulence of $B$. dothidea has been reported on apple fruit and stems $(12,13)$. Latorre and Toledo (12) found that the relative virulence of three isolates of $B$. dothidea differed on apple fruit and 1-yearold apple trees. Proffer and Jones (14) inoculated apple fruit and twigs of 10-yearold trees in the field with several isolates

Corresponding author: P. S. McManus

E-mail: psm@plantpath.wisc.edu

Accepted for publication 6 June 2000 .

Publication no. D-2000--0719-01R

(C) 2000 The American Phytopathological Society of B. obtusa and B. stevensii. B. stevensii always produced larger stem cankers and, in general, larger fruit lesions than $B . o b$ tusa, but no test for correlation between the assays was reported. If there were a positive correlation between the virulence of isolates of Botryosphaeria on apple fruit and virulence on stems, then the relatively quick and convenient fruit assay could be used, for example, to describe populations or identify appropriate isolates for studies in epidemiology or control.

$B$. dothidea and B. obtusa usually infect through pruning wounds or other injury sites on apple trees. Pruning apple trees during the summer for fire blight management, or to open canopies to improve air movement and light penetration, might increase the incidence of infection by $B$. dothidea and $B$. obtusa at a time when trees are more vulnerable to canker development due to drought stress. Recommended control practices for white rot and black rot cankers include pruning out the affected branches and removing other sources of inoculum, such as diseased fruit $(23,24)$. Applying effective fungicides to pruning wounds, either directly or by spraying tree canopies, would give apple growers an additional strategy for disease management. Currently, many growers spray benzimidazole fungicides during the summer to control flyspeck, sooty blotch, and fruit rot diseases. Recently, two strobilurin fungicides, kresoxim-methyl and trifloxystrobin, were registered in the
United States on apple and are expected to be used during the summer to manage these diseases. Effectiveness against the canker phases of black rot and white rot has not been reported but might be a side benefit of fungicides applied for the management of other diseases. Because both $B$. dothidea and B. obtusa have been reported on more than 100 plant genera (7), including valuable landscape trees and shrubs, a new canker management strategy could see wide application.

In this study, the virulence of isolates of $B$. dothidea and B. obtusa was compared on apple fruit, trunks of young apple trees, and twigs of mature apple trees. For these purposes, we defined virulence as the degree to which an isolate produced canker symptoms. We inoculated fruit in order to compare isolates native to Wisconsin with reference isolates, and to determine whether the results of fruit assays were correlated with results of the more laborious stem assays on young trees. We inoculated stems of mature trees in the field in order to compare $B$. dothidea and $B$. obtusa as canker pathogens of apple in Wisconsin. Additionally, several compounds, including the commercial fungicides benomyl, kresoxim-methyl, and trifloxystrobin, were tested for their ability to reduce the incidence and size of cankers incited by $B$. dothidea and $B$. obtusa.

\section{MATERIALS AND METHODS}

Fungal isolates. Fungal isolates used in this study and their geographic and host origins are listed in Table 1. B. dothidea isolates 96-6 and 97-13 and B. obtusa isolates $96-32$ and 151a were provided by G. Stanosz, University of Wisconsin-Madison. All other isolates originated with this study and were derived from single conidia. Fungal species are referred to by teleomorphic names but were identified based on traits of the anamorphic stages, Fusicoccum aesculi and Sphaeropsis malorum for $B$. dothidea and B. obtusa, respectively. Analysis of randomly amplified polymorphic DNA (data not shown) confirmed the similarity of new isolates to reference isolates. Isolates were cultured routinely on potato dextrose agar (PDA) for 5 to 7 days at $25^{\circ} \mathrm{C}$ with a 12 -h photoperiod. Short-term storage was on PDA slants at $4^{\circ} \mathrm{C}$; long-term storage (e.g., from year to year) was on sterile soil (28).

Apple fruit assays. Fruit of the apple cultivar Golden Delicious were inoculated 
with the Botryosphaeria isolates listed in Table 1. The experimental design was completely randomized, with eight singlefruit replications of nine inoculation treatments (eight isolates plus one control). There were two subsamples per replication, with the same isolate being applied to opposite faces of a fruit. Surface-disinfested fruit were inoculated with 5-mmdiameter plugs of mycelia from fungal colony margins. Plugs of PDA were used for the control. Apple fruit tissue was trimmed and repositioned in the hole over the mycelial plug to retain moisture. Treated fruit were placed on plastic trays, enclosed in a plastic bag, and incubated at $25^{\circ} \mathrm{C}$ for 5 days. The lesions produced were measured at equatorial and longitudinal axes that had been marked with indelible ink prior to inoculating fruit. The area of the original wound was not subtracted from final measurements. The experiment was performed twice.

Potted-tree assays. In spring of 1998 and 1999, 1-year-old Golden Delicious apple trees (strain Smoothee on M.7 rootstock in 1998; strain Golden Glory on M.106 rootstock in 1999) were planted in a mixture of one part field soil and one to two parts Metromix (Scott-Sierra Horticultural Products Co., Maryville, OH) in 50-cm-tall tree pots. Trees were placed outdoors and were watered as needed throughout the summer.

In 1998, the experimental design was a completely randomized, repeated measures design with 12 single-tree replications of six inoculation treatments (five isolates plus one control). Only isolates originating in Wisconsin (B. dothidea isolates 97-114 and 97-5, B. obtusa isolates 96-151a, 97115 , and 97-116) were used to avoid introducing nonnative isolates. Tree trunks were inoculated on 7 to $8 \mathrm{July}, 3$ to $10 \mathrm{~cm}$ below new growth, and again with the same isolate on 13 August, about $10 \mathrm{~cm}$ below the first inoculation site. A 5-mm-diameter piece of bark was cut and removed with a cork borer. The wounded area was inoculated with a 4-mm-diameter plug of mycelia from the margins of fungal colonies or PDA as a control. Treated areas were wrapped with masking tape to retain moisture; the tape was removed after 2 weeks. Eight weeks after inoculation, canker area was estimated using the formula for an ellipse. The area of the original wound was not subtracted from final measurements. In 1999, the experiment was repeated with the following modifications. Treatments (five isolates plus PDA control) were applied to 21 single-tree replications. Inoculations were done on 9 July and 27 August using a 6-mm-diameter cork borer and 6-mm-diameter plugs of mycelia or PDA for inoculation of wounds. An additional trial was conducted in 1999 using the Smoothee trees from 1998. The trees had been cut back to remove the cankered portion of the stem in November 1998 and placed in cold storage during the winter. In February 1999, the trees were removed from storage and placed in a greenhouse. On 30 April, tree trunks were wounded and inoculated as described above. The experimental design was as described for 1998, except that the trees were inoculated only once in 1999. After 3 weeks, trees were placed outside. Eight weeks after inoculation, canker area was estimated using the formula for an ellipse.

Isolate virulence and topical wound treatments on mature trees. Isolate virulence and the efficacy of topically applied compounds in reducing canker incidence and size were evaluated in 1998 and 1999 in apple orchards at research stations in Arlington and Sturgeon Bay, WI. At Arlington, experiments were done on 30year-old Golden Delicious trees; at Sturgeon Bay, experiments were done on 35year-old Cortland trees. Neither site was irrigated. The experimental design was a 2way factorial (fungal isolate $x$ wound treatment) with seven two-tree replications (blocks) at Arlington and seven one-tree replications (blocks) at Sturgeon Bay. Each of the isolate $\times$ wound treatment combinations was randomly assigned once per replication. The five fungal isolates used in potted-tree assays plus a PDA control were used in field studies. In 1998, compounds tested and the amounts of formulated product used were: benomyl (Benlate 50W; E. I. du Pont de Nemours and Co., Wilmington, DE), $0.045 \mathrm{~g}$ plus $5 \mu$ Latron B1956 (Rohm and Haas Corp., Philadelphia, PA) per $200 \mathrm{ml}$ of water; kresoxim-methyl (Sovran 50WG; BASF Corp., Research Triangle Park, NC ), 0.045 g per $200 \mathrm{ml}$ of water; garlic extract (Garlic Gard; Soil Technologies Corp., Fairfield, IA), $1 \%$ in water; neem oil (Trilogy; Thermo-Trilogy Corp., Columbia, MD), $1 \%$ in water; clove oil (pharmaceutical grade), $1 \%$ in $95 \%$ ethanol; and water as a control. In 1999,

Table 1. Isolates used in this study and their geographic and host origins

\begin{tabular}{lccc}
\hline Isolate & Origin & Host & Organ isolated from \\
\hline Botryosphaeria dothidea 97-114 & Wisconsin & Apple & Stem \\
B. dothidea 97-5 & Wisconsin & Apple & Stem \\
B. dothidea $97-13$ & North Carolina & Apple & Unknown \\
B. dothidea $96-6$ & Georgia & Peach & Unknown \\
B. obtusa $97-115$ & Wisconsin & Apple & Stem \\
B. obtusa $97-116$ & Wisconsin & Apple & Fruit \\
B. obtusa 96-151a & Wisconsin & Apple & Unknown \\
B. obtusa 96-32 & South Africa & Pistachio & Unknown \\
\hline
\end{tabular}

the same compounds were tested, except that garlic extract was omitted, and trifloxystrobin (Flint 50WG; Novartis Corp., Greensboro, NC), $0.045 \mathrm{~g}$ per $200 \mathrm{ml}$ of water, and ethanol $(95 \%)$ were added. The amounts of commercial products used were consistent with the manufacturers' recommendations for foliar application. In 1998, twigs were pruned at their bases, creating wounds 5 to $10 \mathrm{~mm}$ in diameter on the subtending twigs, which were 18 to $38 \mathrm{~mm}$ in circumference at the wound site. In 1999, instead of pruning twigs to make wounds, a 6-mm-diameter piece of bark was cut and removed from twigs that were 20 to $36 \mathrm{~mm}$ in circumference. In both years, wound treatment compounds were applied with a paintbrush and allowed to dry for 30 to $45 \mathrm{~min}$, after which wounds were inoculated with the fungal isolates or PDA as described for the potted-tree assays. Canker incidence, canker length, and extent of stem girdling were measured 8 weeks after inoculation. The dimensions of the original wound were not subtracted from final measurements. After canker dimensions were recorded, twigs were dissected around the wound site to examine xylem for evidence of dark streaking. Fungal isolation was done for a subset of twigs with (i) cankers and xylem streaking, (ii) cankers but no xylem streaking, (iii) xylem streaking but no cankers, and (iv) neither cankers nor xylem streaking.

Air-blast application of kresoximmethyl for control of cankers. In addition to experiments in which compounds were applied directly to wounded branches, in 1999, kresoxim-methyl was applied with an air-blast sprayer, the standard method of pesticide application used by commercial apple growers. The experimental design was a split plot performed once at Arlington on 30-year-old McIntosh apple trees and once at Sturgeon Bay on 35-year-old Cortland apple trees. Main plot treatments (water or fungicide) consisted of two fivetree blocks at each location. Four replications of each subplot treatment (inoculation with B. dothidea 97-114 or PDA) were randomized within each of four sections (A,B,C,D) of a tree. Sections A and C were adjacent to the next tree in the row, while sections B and D faced the rows and were perpendicular to the direction of spray. A 6-mm-diameter piece of bark was cut and removed from twigs (20 to $38 \mathrm{~mm}$ in circumference); water or kresoxim-methyl (Sovran 50WG [0.22 $\mathrm{g}$ of formulated product per liter]) was applied to main plots with an air-blast sprayer equipped with disk nozzles (1.7 and $2.1 \mathrm{MPa}$ at Sturgeon Bay and Arlington, respectively); and then the fungus was applied to wounds as described previously. The experiment was set up 12 to 15 July and 26 to 28 July at Arlington and Sturgeon Bay, respectively. Canker incidence, canker length, and extent of stem girdling were measured 8 weeks after inoculation. 
Spray coverage was monitored to determine whether it corresponded to any reduction in observed canker incidence and size. Prior to spraying, water sensitive cards were fastened with wire "twist-ties" to each branch directly behind wounds. Areas of cards that were exposed to spray turned from yellow to blue. Cards from both locations were analyzed together to reduce the possibility of introducing error by location. Cards were initially sorted by visual inspection into four categories: (i) 0.1 to $25 \%$, (ii) 25.1 to $50 \%$, (iii) 50.1 to $75 \%$, and (iv) $75.1 \%$ to $100 \%$ spray coverage. These groups were further sorted into three subgroups that represented low, medium, and high levels of coverage within each category. Within these subgroups, cards that were visually determined to have the most and least coverage were rated using Optimas 6.2 image analysis software (Media Cybernetics, Silver Spring, MD). The purpose of image analysis was to get an accurate measure of coverage for a representative subset of cards. Cards were scanned using Sigma ScanPRO4.0 software (SPSS Co., Chicago, IL). An unsprayed yellow card was used to calibrate the software. Scanned images were captured with a Sony 3CCD model DXC-960MD video camera (Sony Electronics Inc., Park Ridge, NJ) and Flash Point 128 Video Frame Grabber (Integral Technologies Inc., Indianapolis, IN). Images were converted to grayscale with maximum contrast, and then separated into two layers by assigning a range of intensities that corresponded to each color. Yellow (unsprayed) and blue (sprayed) areas were quantified as numbers of pixels, which were converted to percent coverage. Finally, the imaged cards were compared to visually sorted cards, and the visually sorted cards were reassigned, as necessary, to the appropriate category.

Table 2. Mean lesion area on Golden Delicious apple fruit 5 days after inoculation with $\mathrm{Bo}$ tryosphaeria spp. $^{\mathrm{x}}$

\begin{tabular}{lcc}
\hline & \multicolumn{2}{c}{ Lesion area $\left(\mathbf{m m}^{2}\right)^{\mathrm{y}}$} \\
\cline { 2 - 3 } Species & Trial I & Trial II \\
\hline B. dothidea $97-5$ & $5,286 \mathrm{a}^{\mathrm{z}}$ & $3,831 \mathrm{ab}$ \\
B. dothidea $97-13$ & $4,823 \mathrm{a}$ & $5,555 \mathrm{a}$ \\
B. dothidea $97-114$ & $4,691 \mathrm{a}$ & $3,977 \mathrm{a}$ \\
B. obtusa $96-32$ & $1,821 \mathrm{~b}$ & $2,371 \mathrm{~b}$ \\
B. obtusa $97-115$ & $1,281 \mathrm{bc}$ & $2,319 \mathrm{~b}$ \\
B. obtusa $96-151 \mathrm{a}$ & $969 \mathrm{c}$ & $376 \mathrm{c}$ \\
B. obtusa $97-116$ & $551 \mathrm{~d}$ & $530 \mathrm{c}$ \\
B. dothidea $96-6$ & $190 \mathrm{e}$ & $697 \mathrm{c}$ \\
Control & $23 \mathrm{f}$ & $22 \mathrm{~d}$ \\
\hline x Each isolate was used to inoculate eight fruit, \\
with the same isolate being applied to oppo- \\
site faces of a fruit (two subsamples per fruit). \\
y The area of the original wound was not sub- \\
tracted from final measurements. Values were \\
transformed by log for $_{10}$ for analysis and separa- \\
tion of means, but actual values are reported. \\
z Values within a column followed by the same \\
letter are not significantly different according \\
to Fisher's protected least significant differ- \\
ence test $(P=0.05)$.
\end{tabular}

Statistical analyses. All statistical analyses were performed using SAS statistical software (Version 7, SAS Institute, Cary, NC). For the apple fruit and pottedtree assays, analysis of variance was by the General Linear Model (GLM) procedure. Data were transformed by $\log _{10}$ to correct for unequal variances, but actual values are reported. Means were separated by Fisher's protected least significant difference (LSD) test with $P=0.05$. For mature trees, analysis of variance for canker length and percent stem girdled was by PROC MIXED. Prior to analysis, the data were ranked using the PROC RANK procedure to correct for unequal variance and nonnormality for canker size, but actual values are reported. Canker incidence on mature trees was analyzed using PROC FREQ to obtain chi-square contingency tables.

\section{RESULTS}

Apple fruit assays. Isolates of $B$. $d o$ thidea produced soft, light tan rot lesions. Isolates of B. obtusa produced firm, dark brown rot lesions. No rot lesions developed on control fruit. In general, $B$. dothidea isolates produced larger lesions than $B$. obtusa isolates (Table 2). One exception was $B$. dothidea 96-6, originally isolated from peach. Isolates from Wisconsin shared LSD groups with isolates from other locations, indicating that the isolates from Wisconsin and elsewhere were comparable in virulence on apple fruit.

Potted-tree assays. Main effects for canker area were significant $(P<0.0001)$ in all trials (Table 3 ). In the repeated measures experiments, isolate $\times$ time of inoculation interactions were significant in both $1998(P=0.0212)$ and $1999(P=$ $0.0108)$, but different isolate $\times$ time combinations accounted for the significance in the 2 years. For example, in 1998, B. dothidea isolate $97-114$ produced the largest cankers in the July inoculations but the smallest cankers (except for the control) in the August inoculations (Table 3). By con- trast, in 1999, B. dothidea isolate $97-5$ and $B$. obtusa isolate $97-115$ performed differently in the July and August trials. In addition to the isolate $\times$ time of inoculation interactions within years, results varied between years. The cankers produced in 1999 on Smoothee trees that had been held over from 1998 were larger than cankers produced in the other two trials.

Correlation of isolate virulence on fruit and stems. Pairwise comparisons of data from the two fruit assays with the five series of stem inoculations (two sets of inoculations in two repeated measures trials plus a third single-inoculation trial) suggested no correlation between isolates' virulence on fruit and stems for nine of the 10 comparisons. Formal statistical analysis of one of the fruit lesion-stem canker comparisons did not demonstrate correlation (data not shown), and further formal analyses were not conducted.

Isolate virulence and topical wound treatments on mature trees. In general, $B$. dothidea isolates produced larger cankers than B. obtusa isolates (Table 4). Stem girdle values were larger for controls in 1998 than 1999 due to the method of wounding. B. dothidea isolates produced more cankers than $B$. obtusa isolates at Arlington in $1998(P=0.009)$ and at Sturgeon Bay in $1999(P=0.0001)$ (Tables 5 and 6). Differences in canker incidence between the fungal species were not significant at Arlington in $1999(P=0.273)$ or at Sturgeon Bay in $1998(P=0.186)$ (Tables 5 and 6). B. dothidea $97-114$ produced as many or more cankers than other isolates, except at Arlington in 1999; $B$. obtusa 96-151a consistently produced the fewest cankers (Tables 5 and 6).

Canker incidence was significantly lower for wounds treated with benomyl, kresoxim-methyl, or trifloxystrobin compared with water-treated controls at both sites during both years (trifloxystrobin not tested in 1998) (Tables 5 and 6). In 1998 at Arlington, treating wounds with garlic

Table 3. Mean canker area on potted 2-year-old apple trees 8 weeks after inoculation with Botryosphaeria spp.

\begin{tabular}{|c|c|c|c|c|c|}
\hline \multirow[b]{3}{*}{ Isolate } & \multicolumn{5}{|c|}{ Canker area $\left(\mathbf{m m}^{2}\right)^{\mathrm{w}}$} \\
\hline & \multicolumn{2}{|c|}{$1998^{x}$} & \multicolumn{2}{|c|}{$1999^{x}$} & \multirow[b]{2}{*}{$1999 y$} \\
\hline & July & August & July & August & \\
\hline B. dothidea $97-114$ & $130 a^{z}$ & $56 \mathrm{c}$ & $65 \mathrm{~b}$ & $86 \mathrm{ab}$ & $259 \mathrm{a}$ \\
\hline B. obtusa $97-116$ & $105 \mathrm{~b}$ & $123 \mathrm{a}$ & $48 \mathrm{~b}$ & $83 \mathrm{ab}$ & $239 \mathrm{a}$ \\
\hline B. dothidea $97-5$ & $82 \mathrm{~b}$ & $66 \mathrm{bc}$ & $98 \mathrm{a}$ & $61 \mathrm{~b}$ & $129 \mathrm{~b}$ \\
\hline B. obtusa $97-115$ & $74 \mathrm{~b}$ & $77 \mathrm{~b}$ & $57 \mathrm{~b}$ & $127 \mathrm{a}$ & $338 \mathrm{a}$ \\
\hline B. obtusa 96-151a & $66 \mathrm{c}$ & $85 \mathrm{ab}$ & $36 \mathrm{~b}$ & $45 \mathrm{~b}$ & $131 \mathrm{~b}$ \\
\hline Control & $9 \mathrm{~d}$ & $24 \mathrm{~d}$ & $11 \mathrm{c}$ & $15 \mathrm{c}$ & $39 \mathrm{c}$ \\
\hline$P>F$ & $<0.0001$ & $<0.0001$ & $<0.0001$ & $<0.0001$ & $<0.0001$ \\
\hline
\end{tabular}

${ }^{\mathrm{w}}$ Canker area was estimated using the formula for an ellipse. The area of the original wound was not subtracted from final measurements. Values were transformed by $\log _{10}$ for analysis and separation of means, but actual values are reported.

${ }^{\mathrm{x}}$ Each isolate was used to inoculate 12 and 21 trees in 1998 and 1999, respectively. Inoculations were done in July and repeated on the same trees in August, in a repeated-measures experiment.

${ }^{y}$ Each isolate was used to inoculate 12 trees once.

${ }^{\mathrm{z}}$ Values within a column followed by the same letter are not significantly different according to Fisher's protected least significant difference test $(P=0.05)$. 
extract or neem oil resulted in significantly fewer cankers than the water-treated control, but these results were not reproduced at Sturgeon Bay in 1998 or at either location in 1999 (Tables 5 and 6). Only benomyl, kresoxim-methyl, and trifloxystrobin consistently reduced canker length and percent stem girdled (Table 7).

There were significant isolate $\times$ wound treatment interactions at Arlington in 1998 ( $P=0.0003$ for canker length; $P=0.0096$ for percent stem girdled), at Sturgeon Bay in $1998(P=0.0491$ for canker length; $P=$ 0.0202 for percent stem girdled), and at Arlington in $1999(P=0.0151$ for canker length; $P=0.0290$ for percent stem gir- dled). Although significant, the $P$-values were not as extreme as $P$-values for main effects $(P<0.0001$ in all cases; Tables 4 and 7). Therefore, for simplicity, overall means are presented (Tables 4 and 7). In order to determine which isolate $x$ wound treatment combinations accounted for the significant interactions, arrays showing the ranks of isolates for each wound treatment were examined. The highly variable rank of B. obtusa 97-116 contributed to the significant interactions for canker length and percent girdle at both locations in 1998 and at Arlington in 1999. This isolate consistently produced the largest cankers on water-treated control stems but generally

Table 4. Effect of isolate on canker size on mature apple trees inoculated with Botryosphaeria dothidea and B. obtusa ${ }^{\mathrm{x}}$

\begin{tabular}{|c|c|c|c|c|}
\hline \multirow{2}{*}{$\begin{array}{l}\text { Year } \\
\text { Isolate }\end{array}$} & \multicolumn{2}{|c|}{ Canker length $(\mathbf{m m})^{y}$} & \multicolumn{2}{|c|}{ Stem girdle $(\%)^{y}$} \\
\hline & Arlington & Sturgeon Bay & Arlington & Sturgeon Bay \\
\hline \multicolumn{5}{|l|}{1998} \\
\hline B. dothidea 97-114 & $16 \mathrm{a}^{\mathrm{z}}$ & $167 \mathrm{a}$ & 39 a & $73 \mathrm{a}$ \\
\hline B. dothidea $97-5$ & $11 \mathrm{ab}$ & $93 \mathrm{ab}$ & $32 \mathrm{ab}$ & $61 \mathrm{ab}$ \\
\hline B. obtusa $97-115$ & $9 \mathrm{ab}$ & $30 \mathrm{c}$ & $32 \mathrm{ab}$ & $42 \mathrm{c}$ \\
\hline B. obtusa $97-116$ & $9 \mathrm{~b}$ & $50 \mathrm{bc}$ & $32 \mathrm{ab}$ & $55 \mathrm{bc}$ \\
\hline B. obtusa 96-151a & $8 \mathrm{bc}$ & $11 \mathrm{~d}$ & $29 \mathrm{~b}$ & $32 \mathrm{~d}$ \\
\hline Control & $7 \mathrm{c}$ & $7 \mathrm{e}$ & $25 \mathrm{c}$ & $24 \mathrm{e}$ \\
\hline$P>F$ & $<0.0001$ & $<0.0001$ & $<0.0001$ & $<0.0001$ \\
\hline \multicolumn{5}{|l|}{1999} \\
\hline B. dothidea 97-114 & $9 \mathrm{a}$ & $28 \mathrm{a}$ & $22 \mathrm{a}$ & $39 \mathrm{a}$ \\
\hline B. dothidea $97-5$ & $7 \mathrm{a}$ & $9 \mathrm{a}$ & $22 \mathrm{a}$ & $39 \mathrm{a}$ \\
\hline B. obtusa $97-115$ & $8 \mathrm{a}$ & $6 \mathrm{~b}$ & $26 \mathrm{a}$ & $22 \mathrm{~b}$ \\
\hline B. obtusa $97-116$ & $9 \mathrm{a}$ & $6 \mathrm{~b}$ & $28 \mathrm{a}$ & $22 \mathrm{~b}$ \\
\hline B. obtusa 96-151a & $8 \mathrm{a}$ & $6 \mathrm{~b}$ & $25 \mathrm{a}$ & $19 \mathrm{~b}$ \\
\hline Control & $4 \mathrm{~b}$ & $5 \mathrm{c}$ & $8 \mathrm{~b}$ & $14 \mathrm{c}$ \\
\hline$P>F$ & $<0.0001$ & $<0.0001$ & $<0.0001$ & $<0.0001$ \\
\hline
\end{tabular}

${ }^{\mathrm{x}}$ Cultivars Golden Delicious and McIntosh at Arlington and Sturgeon Bay, respectively. Twigs were wounded, treated with water or chemical compounds, and then inoculated with isolates of $B$. dothidea or $B$. obtusa. Values for each fungal isolate were averaged over all wound treatments. Means of 42 and 49 values for each isolate in 1998 and 1999, respectively.

y The dimensions of the original wound were not subtracted from final measurements. Values were ranked for analysis and separation of means, but actual values are reported.

${ }^{\mathrm{z}}$ Values within a column followed by the same letter are not significantly different according to Fisher's protected least significant difference test $(P=0.05)$. ranked low for twigs treated with benomyl, and in some cases, with at least one other wound treatment. There were additional isolate $\times$ wound treatment combinations that contributed to the significant interaction in various experiments, but no trends were detected.

Air-blast application of kresoximmethyl. Canker incidence was significantly lower on trees sprayed with kresoximmethyl than on trees sprayed with water $(P$ $<0.0001)$. At Arlington, the numbers of cankers were 59 and 28 on trees sprayed with water or kresoxim-methyl, respectively; at Sturgeon Bay, the numbers of cankers were 43 and 25 on trees sprayed with water or kresoxim-methyl, respectively. Inoculation of wounds with $B$. dothidea 97114 resulted in significantly larger cankers than inoculation of wounds with PDA $(P<$ 0.0001). For twigs inoculated with $B$. dothidea 97-114, there were significant differences between water-sprayed and fungicidesprayed trees for both canker length and percent stem girdled, but there were no significant differences based on the amount of fungicide coverage (Table 8). For percent stem girdled, there was no significant difference in rank of cankers on water-sprayed trees ( $42 \%$ girdled) and cankers whose corresponding cards had received 25.1 to $50 \%$ fungicide coverage (34\% girdled) (Table 8 ). However, ranking reduces the leverage of extreme values; LSD groupings may therefore be different for the ranked data versus the original data. Coverage of cards in tree sections $\mathrm{A}$ and $\mathrm{C}$ was 33 and $32 \%$, respectively, which was significantly less than coverage of cards in sections B and D (49\% for each). This difference in coverage, however, did not affect canker length or percent stem girdled (data not shown).

Recovery of Botryosphaeria spp. from cankers and xylem tissue. For each site and year, fungal isolations were done for

Table 5. Effects of topically applied wound treatments of Botryosphaeria spp. on numbers of cankers on mature apple trees, $1998^{\mathrm{y}}$

\begin{tabular}{|c|c|c|c|c|c|c|c|}
\hline \multirow{2}{*}{$\begin{array}{l}\text { Site } \\
\text { Isolate }\end{array}$} & \multicolumn{7}{|c|}{ Wound treatment } \\
\hline & Benomyl & Clove & Garlic & Kresoxim-methyl & Neem & Water & Total \\
\hline \multicolumn{8}{|l|}{ Arlington } \\
\hline B. dothidea $97-114$ & 5 & 3 & 5 & 3 & 7 & 7 & 30 \\
\hline B. dothidea $97-5$ & 1 & 7 & 4 & 2 & 6 & 5 & 25 \\
\hline B. obtusa $97-115$ & 0 & 7 & 3 & 1 & 5 & 3 & 19 \\
\hline B. obtusa 97-116 & 0 & 7 & 5 & 1 & 2 & 6 & 21 \\
\hline B. obtusa 96-151a & 1 & 7 & 1 & 0 & 0 & 4 & 13 \\
\hline Control & 0 & 3 & 0 & 0 & 0 & 1 & 4 \\
\hline Total & 7 & 34 & 18 & 7 & 20 & 26 & 112 \\
\hline$P^{\mathrm{z}}$ & $<0.001$ & 0.21 & 0.02 & $<0.001$ & 0.05 & $\ldots$ & $\ldots$ \\
\hline \multicolumn{8}{|l|}{ Sturgeon Bay } \\
\hline B. dothidea $97-114$ & 4 & 7 & 6 & 4 & 7 & 5 & 33 \\
\hline B. dothidea $97-5$ & 3 & 7 & 6 & 4 & 6 & 6 & 32 \\
\hline B. obtusa $97-115$ & 1 & 7 & 7 & 3 & 7 & 7 & 32 \\
\hline B. obtusa 97-116 & 1 & 6 & 7 & 5 & 7 & 7 & 33 \\
\hline B. obtusa 96-151a & 2 & 6 & 3 & 2 & 5 & 4 & 22 \\
\hline Control & 0 & 0 & 0 & 0 & 1 & 0 & 1 \\
\hline Total & 11 & 33 & 29 & 18 & 33 & 29 & 153 \\
\hline$P^{\mathrm{z}}$ & $<0.001$ & 0.32 & 1.00 & 0.02 & 0.32 & $\ldots$ & $\ldots$ \\
\hline
\end{tabular}

${ }^{y}$ Experimental design was a two-way factorial (fungal isolate $\times$ wound treatment) with seven replications. Values are the number of cankers that resulted from inoculation of seven twigs.

${ }^{\mathrm{z}}$ Significance of chi-square test for differences in canker incidence between the water treatment and each of the other treatments. 
54 to 165 twigs. The species of Botryosphaeria used to inoculate the twig was recovered at a frequency of 97 to $100 \%$, whether symptoms (cankers or dark streaking in the xylem) were present or not. B. obtusa and B. dothidea were isolated from one and zero, respectively, of 22 twigs that had been wounded but not inoculated.

\section{DISCUSSION}

The relative virulence of isolates of $B$. dothidea and B. obtusa varied depending upon the type of assay used. The fruit inoculation assay was relatively simple, and results were similar in two trials (Table 2). However, the results of the fruit assay did not correlate with results of the potted-tree assay, precluding the future use of the fruit assay to assess isolates' potential as stem canker pathogens. The lack of correlation between the apple fruit assays and pottedtree assays, and the variable results for the latter, might be attributed in part to differences in temperature. Temperature was controlled for fruit in an incubator but fluctuated for potted trees outdoors. The lack of repeatability of the potted-tree assay would limit the usefulness of this method to assess pathogen virulence. In general, $B$. dothidea isolates were more virulent than $B$. obtusa isolates on both apple fruit and twigs of mature trees in the field, but differences in experimental design between fruit and mature-tree experiments prohibited a formal test for correlation.

B. obtusa and B. stevensii, but not $B$. dothidea, were among the fungi found associated with apple cankers in a survey of 26 orchards in Michigan (14). By contrast, at the outset of our study, when we sought native isolates to use in field studies, $B$. dothidea was readily found, suggesting that it is not rare in southern Wis- consin. The relatively high virulence of $B$. dothidea on mature trees in our study suggests that it is a capable pathogen of apple in Wisconsin, at least during late summer, the warmest time of year. In the southern United States, B. dothidea is considered a more serious canker pathogen of apple than $B$. obtusa, presumably because the relatively warm climate is less favorable to $B$. obtusa (4). In Georgia, the prevalence of Botryosphaeria spp. associated with peach twigs fluctuated over a 2-year period, with $B$. dothidea prevailing during summer and $B$. obtusa prevailing during winter and spring (3). Thus, our results might have been different had we inoculated twigs in the spring rather than summer. We also acknowledge that virulence factors involved in natural infection by spores would have been circumvented in our artificial inoculation with mycelia. However, an early attempt to inoculate trees in the field with conidial suspensions ( 2 to $4 \times 10^{4}$ conidia per $\mathrm{ml}$ of water) resulted in only six cankers on 372 twigs inoculated (data not shown), so this method was abandoned in further tests.

Our findings are consistent with previous reports that physiological stresses, especially drought stress, predispose trees

Table 7. Effect of topically applied wound treatments on canker size on mature apple trees inoculated with Botryosphaeria dothidea and B. obtusa ${ }^{\mathrm{x}}$

\begin{tabular}{|c|c|c|c|c|}
\hline \multirow{2}{*}{$\begin{array}{l}\text { Year } \\
\text { Treatment }\end{array}$} & \multicolumn{2}{|c|}{ Canker length $(\mathrm{mm})^{\mathrm{y}}$} & \multicolumn{2}{|c|}{ Stem girdled $(\%)^{y}$} \\
\hline & Arlington & Sturgeon Bay & Arlington & Sturgeon Bay \\
\hline \multicolumn{5}{|l|}{1998} \\
\hline Water & $11 \mathrm{~b}^{\mathrm{z}}$ & $67 \mathrm{a}$ & $33 \mathrm{~b}$ & $54 \mathrm{a}$ \\
\hline Clove & $13 \mathrm{a}$ & $102 \mathrm{a}$ & $42 \mathrm{a}$ & $56 \mathrm{a}$ \\
\hline Garlic & $11 \mathrm{bc}$ & $67 \mathrm{a}$ & $33 \mathrm{~b}$ & $58 \mathrm{a}$ \\
\hline Neem & $11 \mathrm{~cd}$ & $57 \mathrm{a}$ & $33 \mathrm{~b}$ & $52 \mathrm{a}$ \\
\hline Benomyl & $7 \mathrm{~d}$ & $31 \mathrm{~b}$ & $25 \mathrm{c}$ & $33 \mathrm{~b}$ \\
\hline Kresoxim-methyl & $7 \mathrm{~d}$ & $24 \mathrm{~b}$ & $24 \mathrm{c}$ & $34 \mathrm{~b}$ \\
\hline$P>F$ & $<0.0001$ & $<0.0001$ & $<0.0001$ & $<0.0001$ \\
\hline \multicolumn{5}{|l|}{1999} \\
\hline Water & $9 \mathrm{a}$ & $17 \mathrm{ab}$ & $26 \mathrm{a}$ & $30 \mathrm{~b}$ \\
\hline Ethanol & $8 \mathrm{a}$ & $7 \mathrm{~cd}$ & $24 \mathrm{~b}$ & $26 \mathrm{bc}$ \\
\hline Clove & $9 \mathrm{a}$ & $8 \mathrm{a}$ & $29 \mathrm{a}$ & $35 \mathrm{a}$ \\
\hline Neem & $9 \mathrm{a}$ & $21 \mathrm{bc}$ & $30 \mathrm{a}$ & $30 \mathrm{~b}$ \\
\hline Benomyl & $5 \mathrm{c}$ & $7 \mathrm{de}$ & $9 \mathrm{c}$ & $21 \mathrm{~cd}$ \\
\hline Kresoxim-methyl & $6 \mathrm{~b}$ & $6 \mathrm{de}$ & $16 \mathrm{~b}$ & $21 \mathrm{~cd}$ \\
\hline Trifloxystrobin & $5 \mathrm{~b}$ & $6 \mathrm{de}$ & $15 \mathrm{~b}$ & $19 \mathrm{~d}$ \\
\hline$P>F$ & $<0.0001$ & $<0.0001$ & $<0.0001$ & $<0.0001$ \\
\hline
\end{tabular}

${ }^{x}$ Cultivars Golden Delicious and McIntosh at Arlington and Sturgeon Bay, respectively. Twigs were wounded, treated with water or chemical compounds, and then inoculated with isolates of $B$. dothidea or $B$. obtusa. Values for each wound treatment were averaged over all fungal isolates. Means of 42 values for each wound treatment in both 1998 and 1999.

y The dimensions of the original wound were not subtracted from final measurements. Values were ranked for analysis and separation of means, but actual values are reported.

${ }^{\mathrm{z}}$ Values within a column followed by the same letter are not significantly different according to Fisher's protected least significant difference test $(P=0.05)$.

Table 6. Effects of topically applied wound treatments of Botryosphaeria spp. on numbers of cankers on mature apple trees, 1999y

\begin{tabular}{|c|c|c|c|c|c|c|c|c|}
\hline \multirow{2}{*}{$\begin{array}{l}\text { Site } \\
\text { Isolate }\end{array}$} & \multicolumn{8}{|c|}{ Wound treatment } \\
\hline & Benomyl & Clove & Ethanol & Kresoxim-methyl & Neem & Trifloxystrobin & Water & Total \\
\hline \multicolumn{9}{|l|}{ Arlington } \\
\hline B. dothidea 97-114 & 1 & 3 & 5 & 2 & 2 & 1 & 2 & 16 \\
\hline B. dothidea $97-5$ & 1 & 4 & 3 & 1 & 4 & 0 & 2 & 15 \\
\hline B. obtusa $97-115$ & 0 & 6 & 3 & 2 & 5 & 1 & 3 & 20 \\
\hline B. obtusa $97-116$ & 0 & 4 & 4 & 3 & 5 & 3 & 6 & 25 \\
\hline B. obtusa 96-151a & 0 & 2 & 2 & 1 & 1 & 2 & 3 & 11 \\
\hline Control & 0 & 0 & 0 & 0 & 0 & 0 & 0 & 0 \\
\hline Total & 2 & 18 & 17 & 9 & 17 & 7 & 17 & 87 \\
\hline$P^{z}$ & $<0.001$ & 0.82 & 1.00 & 0.06 & 1.00 & 0.02 & $\ldots$ & $\ldots$ \\
\hline \multicolumn{9}{|l|}{ Sturgeon Bay } \\
\hline B. dothidea $97-114$ & 2 & 6 & 2 & 3 & 4 & 2 & 5 & 24 \\
\hline B. dothidea $97-5$ & 2 & 3 & 4 & 2 & 6 & 2 & 5 & 24 \\
\hline B. obtusa $97-115$ & 0 & 2 & 1 & 0 & 1 & 0 & 2 & 6 \\
\hline B. obtusa $97-116$ & 0 & 4 & 0 & 0 & 0 & 0 & 3 & 7 \\
\hline B. obtusa $96-151 \mathrm{a}$ & 0 & 1 & 1 & 0 & 0 & 0 & 0 & 2 \\
\hline Control & 0 & 0 & 0 & 0 & 0 & 0 & 0 & 0 \\
\hline Total & 4 & 16 & 8 & 5 & 11 & 4 & 15 & 63 \\
\hline$P^{\mathrm{z}}$ & 0.004 & 0.82 & 0.08 & 0.01 & 0.34 & 0.004 & $\ldots$ & $\ldots$ \\
\hline
\end{tabular}

${ }^{y}$ Experimental design was a 2-way factorial (fungal isolate $\times$ wound treatment) with seven replications. Values are the number of cankers that resulted from inoculation of seven twigs.

${ }^{\mathrm{z}}$ Significance of chi-square test for differences in canker incidence between the water treatment and each of the other treatments. 
to cankers caused by Botryosphaeria spp. $(6,18,19)$. Canker incidence and size were greatest at Sturgeon Bay in 1998, where $3.6 \mathrm{~cm}$ of rain fell during the month preceding inoculation compared with $8.6 \mathrm{~cm}$ of rain at Arlington. In 1999, 11.0 and 5.8 $\mathrm{cm}$ of rain fell at Sturgeon Bay and Arlington, respectively, during the month preceding inoculation, and both sites received heavy rains shortly after inoculation. Likewise, cankers were much larger on the potted trees that had been held over the winter and inoculated than on trees that were inoculated the same season they were potted (Table 3). The trees that overwintered in pots appeared healthy when leaves emerged, but during the course of the experiment, foliage became sparse and chlorotic, indicative of low vigor.

Treating wounds with benomyl, kresoxim-methyl, or trifloxystrobin resulted in significantly fewer cankers and reduced external canker symptoms compared with other treatments and the control (Tables 5 to 7). In general, benomyl was better than the strobilurin fungicides in reducing canker incidence. The current label for Benlate, the benomyl formulation widely used in commercial orchards, recommends applying the fungicide as a wound dressing to protect peach from Cytospora canker. Applying benomyl directly to pruning wounds on apple at a concentration 10-fold higher than recommended on the current Benlate label was proposed to protect stems from infection by $B$. dothidea (4), although this use was never made legal. Kresoximmethyl and trifloxystrobin are moderately effective in reducing leaf spot and fruit rot caused by $B$. obtusa $(15,16,26)$ and less effective in reducing fruit rot caused by $B$. dothidea $(10,25)$. To the best of our knowledge, our study is the first in which the efficacy of strobilurin fungicides on the canker phases of black rot and white rot has been studied. Topical application of fungicides directly to wounds requires little material and results in little off-target application but is too slow and laborious to be practical in commercial orchards.
Moreover, this use pattern is currently not permitted for fungicides commonly used by apple growers. Our data suggest, however, that application of kresoxim-methyl with an air-blast sprayer for control of apple scab, flyspeck, sooty blotch, or fruit rots, at concentrations similar to those recommended on the current product label, will reduce external canker symptoms caused by Botryosphaeria spp. (Table 8). The fact that canker symptoms were reduced despite incomplete spray coverage is notable because pruning wounds are frequently deep within the tree canopy, where complete spray coverage is problematic.

Growers and researchers frequently place water-sensitive cards in crop canopies in order to monitor pesticide coverage of plant tissues. Visual assessment of spray coverage on cards is subjective, however, and if a large number of cards is evaluated, the chance for error is great. In our study, image analysis on a subset of cards served as a check on the initial sorting by visual inspection. On a per card basis, image analysis was more time-consuming than visual inspection, so it was not practical to image all cards. However, in smaller experiments, the time invested in image analysis might be worth the gain in accuracy and consistency in quantification of coverage. Consistency would be especially important if different people evaluated cards in different trials (e.g., from year to year).

Treating wounds with clove oil, garlic extract, and neem oil failed to reduce canker incidence or size compared with water. In fact, treating wounds with clove oil sometimes resulted in larger cankers than treating wounds with water, despite previous reports of fungitoxic activity of clove oil $(2,20)$, including activity against $B$. dothidea (11). In various studies, garlic extract has been fungitoxic in vitro $(1,21,27)$ and to a lesser extent in vivo $(8,22)$. Clove oil and garlic extract are accepted by some organic certification programs, but our data suggest that they are unlikely to benefit organic apple grow-

Table 8. Effect of kresoxim-methyl air-blast spray coverage on canker size on mature apple trees inoculated with Botryosphaeria dothidea isolate $97-114^{\mathrm{u}}$

\begin{tabular}{lccc}
\hline $\begin{array}{l}\text { Kresoxim-methyl } \\
\text { spray coverage (\%) }\end{array}$ & No. twigs $^{\mathbf{w}}$ & ${\text { Canker length }(\mathbf{m m})^{\mathbf{x}}}^{\mathbf{x}}$ & Stem girdle (\%) $^{\mathbf{x}}$ \\
\hline $0^{\mathrm{y}}$ & 240 & $44 \mathrm{a}^{\mathrm{z}}$ & $42 \mathrm{a}$ \\
$0.1-25$ & 47 & $16 \mathrm{~b}$ & $35 \mathrm{~b}$ \\
$25.1-50$ & 76 & $9 \mathrm{~b}$ & $34 \mathrm{ab}$ \\
$50.1-75$ & 97 & $10 \mathrm{~b}$ & $32 \mathrm{~b}$ \\
$75.1-100$ & 100 & $9 \mathrm{~b}$ & $30 \mathrm{~b}$ \\
\hline
\end{tabular}

u Experimental design was a split-plot with five-tree blocks of the cultivars McIntosh and Cortland at Arlington and Sturgeon Bay, respectively. Twigs were wounded, sprayed with water or kresoximmethyl, and then inoculated with $B$. dothidea isolate 97-114.

${ }^{\mathrm{v}}$ Spray coverage was estimated from water-sensitive cards that were affixed to test twigs.

w The number of twigs in each spray coverage category.

${ }^{x}$ The dimensions of the original wound were not subtracted from final measurements. Values were ranked for analysis and separation of means, but actual values are reported.

${ }^{\mathrm{y}}$ Coverage on water-sprayed control trees was designated as $0 \%$ kresoxim-methyl spray coverage.

${ }^{\mathrm{z}}$ Values within a column followed by the same letter are not significantly different according to Fisher's protected least significant difference test $(P=0.05)$.

ers in managing cankers caused by $B$. dothidea and B. obtusa. Neem oil is commonly used by organic growers for insect and mite control and purportedly acts as a fungicide by preventing the adhesion of fungal spores. Thus, its failure in our study to prevent canker development following inoculation with mycelia is not surprising. Nevertheless, our data suggest that neem oil does not inhibit mycelial growth of $B$. dothidea and B. obtusa on apple stems.

Despite the reduction in external canker symptoms with benomyl, kresoximmethyl, and trifloxystrobin, none of these fungicides reduced colonization of xylem vessels by either $B$. dothidea or $B$. obtusa. Recovery of Botryosphaeria spp. from inoculated stems was nearly $100 \%$ whether or not cankers or xylem streaking were noted. Light microscopy of darkly streaked wood revealed hyphae in xylem vessels (data not shown). The presence of $B$. dothidea and $B$. obtusa in xylem tissue has been reported $(4,5,9)$, although the importance of xylem colonization as a survival mechanism for Botryosphaeria spp. on apple has not been investigated. The systemic persistence of Fusicoccum sp., later reclassified as the anamorph of $B$. dothidea, was shown to be important in the development of cankers on mountain ash (17). Trees inoculated with Fusicoccum sp. remained free of any visible symptoms as long as they were growing vigorously. When trees were stressed by transplanting or prolonged drought, cankers developed and killed the trees. Numerous secondary cankers appeared above and below the inoculation sites, and, similar to our findings, the pathogen was recovered from apparently healthy stem tissues. If $B o$ tryosphaeria spp. are systemic in apple xylem, then the inability of benomyl, kresoxim-methyl, and trifloxystrobin to control xylem colonization will limit their value in controlling the canker phases of black rot and white rot. The ecological significance of colonization of apple tissue by $B$. dothidea and $B$. obtusa must be assessed when developing management strategies for white rot and black rot cankers.

\section{ACKNOWLEDGMENTS}

We thank V. Best, R. Caldwell, V. Gaertner, M Hurkman, M. Kennelly, A. Krueger, B. Schauske, M. Stasiak, and R. Weidman for technical assistance; M. Clayton and R. Voland for advice on experimental design and statistical analyses; Hilltop Nurseries, LLC, for providing trees; and T. Roper and G. Stanosz for reviewing an earlier version of this manuscript. This project was supported in part by the Riker Endowment of the Department of Plant Pathology, University of Wisconsin-Madison.

\section{LITERATURE CITED}

1. Bianchi, A., Zambonelli, A., Zechini D'Aulerio, A., and Bellesia, F. 1997. Ultrastructural studies of the effects of Allium sativum on phytopathogenic fungi in vitro. Plant Dis. 81:1241-1246.

2. Bowers, J. H., and Locke, J. C. 2000. Effect 
of botanical extracts on the population density of Fusarium oxysporum in soil and control of Fusarium wilt in the greenhouse. Plant Dis. 84:300-305.

3. Britton, K. O., and Hendrix, F. F. 1986. Population dynamics of Botryosphaeria spp. in peach gummosis cankers. Plant Dis. 70:134-136.

4. Brown, E. A., II, and Britton, K. O. 1986. Botryosphaeria diseases of apple and peach in the southeastern United States. Plant Dis. 70:480-484.

5. Brown, E. A., II, and Hendrix, F. F. 1981. Pathogenicity and histopathology of Botryosphaeria dothidea on apple stems. Phytopathology 71:375-379.

6. Conner, S. R. 1968. Canker formation on apple bark by Botryosphaeria ribis. Ph.D. thesis. University of Delaware, Newark.

7. Farr, D. F., Bills, G. F., Chamuris, G. P., and Rossman, A. Y. 1989. Fungi on Plants and Plant Products in the United States. American Phytopathological Society, St. Paul, MN.

8. Garcia, R. P., and Padilla, C. L. 1995. Evaluation of potential plant materials against some seedborne fungal pathogens of corn. Philipp. J. Biotechnol. 5:159.

9. Hesler, L. R. 1916. Black rot, leaf spot and canker of pomaceous fruits. Cornell Univ. Agric. Exp. Stn. Bull. 379

10. Hickey, K. D., May, J., and McGlaughlin, E. 1999. Disease incidence on apple sprayed with concentrate fungicide mixtures applied airblast in 1998. Fungic. Nematicide Tests 54:8.

11. Jacobs, K. A., Carter, M. A., and Locke, J. C. 1996. Inhibition of Botryosphaeria dothidea by botanical extracts, insecticidal soap and clove oil. Biol. Cultural Tests Control Plant
Dis. 11:47.

12. Latorre, B. A., and Toledo, M. V. 1984. Occurrence and relative susceptibility of apple cultivars to Botryosphaeria canker in Chile. Plant Dis. 68:36-39.

13. Parker, K. C., and Sutton, T. B. 1993. Susceptibility of apple fruit to Botryosphaeria dothidea and isolate variation. Plant Dis. 77:385-389.

14. Proffer, T. J., and Jones, A. L. 1989. A new canker disease of apple caused by Leucostoma cincta and other fungi associated with cankers on apple in Michigan. Plant Dis. 73:508-514.

15. Rosenberger, D. A., Meyer, F. W., and EngleAhlers, C. A. 1998. Evaluation of new fungicides for apples, 1997. Fungic. Nematicide Tests 53:23.

16. Rosenberger, D. A., Meyer, F. W., and EngleAhlers, C. A. 1999. Evaluation of Vangard and two strobilurin fungicides for controlling apple diseases, 1998. Fungic. Nematicide Tests 54:20.

17. Schoeneweiss, D. F. 1965. Fusicoccum canker of mountain ash in Illinois. Plant Dis. Rep. 49:251-252.

18. Schoeneweiss, D. F. 1975. Predisposition, stress, and plant disease. Annu. Rev. Phytopathol. 13:193-211.

19. Schoeneweiss, D. F. 1978. Water stress as a predisposing factor in plant disease. Pages 6199 in: Water Deficits and Plant Growth. Vol. 5. T. T. Kozlowski, ed. Academic Press, New York.

20. Scholz, K., Vogt, M., and Kunz, B. 1999. Application of plant extracts for controlling fungal infestation of grains and seed during storage. Pages 429-435 in: Modern Fungicides and Antifungal Compounds II. H. Lyr, P.
E. Russell, H. W. Dehne, and H. D. Sisler, eds. Intercept Ltd., Andover, UK.

21. Singh, U. P., Pathak, K. K., Khare, M. N., and Singh, R. B. 1979. Effect of leaf extract of garlic on Fusarium oxysporum f. sp. ciceri, Sclerotinia sclerotiorum and on gram seeds. Mycologia 71:556-563.

22. Singh, U. P., Singh, R. B., and Chauhan, V. B. 1984. Effect of some fungicides, plant extracts and an oil on inoculum density of different nodal leaves of pea infected by Erysiphe polygoni. Z. Pflanzenkrankh. Pflanzenshutz. 91:20-26.

23. Sutton, T. B. 1991. White rot. Pages 16-18 in: Compendium of Apple and Pear Diseases. A L. Jones and H. S. Aldwinckle, eds. American Phytopathological Society, St. Paul, MN.

24. Sutton, T. B. 1991. Black rot. Pages $18-20$ in: Compendium of Apple and Pear Diseases. A. L. Jones and H. S. Aldwinckle, eds. American Phytopathological Society, St. Paul, MN.

25. Sutton, T. B., Anas, O., and Tang, S. 1999. Summer disease control on Golden Delicious and Red Delicious, 1998. Fungic. Nematicide Tests 54:26.

26. Sutton, T. B., Anas, O., and Tang, S. 1999. Disease control on Rome Beauty, 1998. Fungic. Nematicide Tests 54:27.

27. Tansley, M. R., and Appleton, J. A. 1975. Inhibition of fungal growth by garlic extract. Mycologia 67:409-413.

28. Tuite, J. F. 1969. Preservation of microorganisms. Pages 193-203 in: Plant Pathologica Methods: Fungi and Bacteria. Burgess Publishing Co., Minneapolis, MN.

29. Wene, E. G., and Schoeneweiss, D. F. 1980 Localized freezing predisposition to Botryosphaeria canker in differentially frozen woody stems. Can. J. Bot. 58:1455-1458. 